\title{
СМИСЛИ ТА КОДИ В ІНСТРУМЕНТАЛЬНИХ ТВОРАХ О. ЩЕТИНСЬКОГО
}

\section{Савченко Г. С.}

\section{ВСТУП}

Композиторська творчість потребує наукової рефлексії. Не тільки ретроспективної, що перекидає місточок від сьогодення до минулого, але й у просторі сучасності зі всіма оціночними похибками та фрагментарністю, породженими близькістю від досліджуваного явища чи процесу. Творчість О. Щетинського (нар. 1960 року) - добре знаного й визнаного композитора в Україні та за ії межами - не потребує оціночних суджень. О. Щетинський - композитор, який однозначно «відбувся». Причому «відбувся» давно й досить швидко після завершення навчання в класі В. Борисова в Харківському державному інституті мистецтв імені I. Котляревського. Свідченням професійного визнання його як композитора $\epsilon$ активна концертна практика, співпраця 3 відомими виконавцями, видання нот і запис компактдисків ${ }^{1}$. Сьогодні творчість О. Щетинського потребує вдумливої системної аналітики, чи то пак сучасна музикознавча думка потребує активнішого звернення до творів О. Щетинського як яскравого й самобутнього композитора сучасної української музики. Тим більше, що він і сам є вдумливим музикознавцем, який чуйно й професійно відрефлексовує в наукових працях сучасні

${ }^{1}$ Відсилаємо до офіційного сайту О. Щетинського та різномовних сторінок у Вікіпедії, де можна знайти інформацію щодо творчого шляху композитора й тих «університетів», які він пройшов у професійному становленні; написаних творів, нагород на Міжнародних конкурсах, списку колективів і виконавців, із якими він співпрацює тощо:

_ https://web.archive.org/web/20120112023019/http://shchetynsky.16mb.com/\#oth er\%20sites;

- https://ru.wikipedia.org/wiki/\%D0\%A9\%D0\%B5\%D1\%82\%D0\%B8\%D0\%BD\% D1\%81\%D0\%BA\%D0\%B8\%D0\%B9,_\%D0\%90\%D0\%BB\%D0\%B5\%D0\%BA\%D1\%8 1\%D0\%B0\%D0\%BD\%D0\%B4\%D1\%80_\%D0\%A1\%D1\%82\%D0\%B5\%D0\%BF\%D0\% B0\%D0\%BD\%D0\%BE\%D0\%B2\%D0\%B8\%D1\%87;

- https://uk.wikipedia.org/wiki/\%D0\%A9\%D0\%B5\%D1\%82\%D0\%B8\%D0\%BD $\% \mathrm{D} 1 \% 81 \% \mathrm{D} 1 \% 8 \mathrm{C} \% \mathrm{D} 0 \% \mathrm{BA} \% \mathrm{D} 0 \% \mathrm{~B} 8 \% \mathrm{D} 0 \% \mathrm{~B} 9+\% \mathrm{D} 0 \% 9 \mathrm{E} \% \mathrm{D} 0 \% \mathrm{BB} \% \mathrm{D} 0 \% \mathrm{~B} 5 \% \mathrm{D} 0 \%$ BA\%D1\%81\%D0\%B0\%D0\%BD\%D0\%B4\%D1\%80_\%D0\%A1\%D1\%82\%D0\%B5\%D0 $\% \mathrm{BF} \% \mathrm{D} 0 \% \mathrm{~B} 0 \% \mathrm{D} 0 \% \mathrm{BD} \% \mathrm{D} 0 \% \mathrm{BE} \% \mathrm{D} 0 \% \mathrm{~B} 2 \% \mathrm{D} 0 \% \mathrm{~B} 8 \% \mathrm{D} 1 \% 87$

- https://en.wikipedia.org/wiki/Alexander_Shchetynsky 
музичні реалії ${ }^{2}$, тому актуальним, на нашу думку, $є$ звернення до тих творів композитора, які ще не поставали предметом спеціального дослідження. Це Літургійний концерт для фортепіано 3 оркестром (2015 рік) та «Земля Франца Йозефа» для оркестру (2011 рік).

\section{1. Конфігурації смислів у Літургійному концерті для фортепіано з оркестром}

Фортепіанний концерт «Літургійний» створено 2015 року й присвячено піаністові та диригентові Денису Прощаєву (нар. 1978 року). У бесіді з музикознавицею Ю. Бентею О. Щетинський розповів, що прем'єру було здійснено в Німеччині з філармонійним оркестром Майнца, причому концерти відбулися в соборі в центрі міста. Стосовно програмного задуму композитор зауважує таке: ««Літургійний» складається 3 семи частин, кожна 3 яких має назву одного з розділів традиційного латинського реквієму. В історії музики $є$ кілька подібних прикладів - Літургійна третя симфонія А. Онеггера, Симфонія-реквієм (Sinfonia da Requiem) Б. Бриттена. Але про інструментальні концерти у формі літургії я не знаю, тут я освоював цілину. Із моїм хоровим Реквіємом музика Концерту ніяк не пов'язана, це ще одне втілення вічної теми «смерті й просвітлення»»» ${ }^{3}$. На питання Ю. Бенті про те, яким чином удалося поєднати два жанри зі стійкими традиціями, а саме сольний концерт і реквієм, композитор відповідає, що в Концерті він заздалегідь визначив архітектоніку, хоча зазвичай загальний план цілого народжується в процесі творення. «Першу частину "Te decet hymnиs" («Тобі співаємо гімн») я зробив прологом, який передає основні ідеї всієї композиції. Частини від другої до шостої об'єднані у великий другий розділ, назви частин походять із

${ }^{2}$ Назвемо деякі з останніх музикознавчих праць О. Щетинського:

1. Щетинський О. Лінії. Перехрестя. Акценти: Композитор Леонід Грабовський. Бесіди, статті, матеріали. Ідея, укладання, загальне редагування - Олександр Щетинський. Харків : Акта, 2018. 780 с.

2. Щетинський О. Своє і чуже: співіснування авторського і запозиченого в сучасному музичному творі. Аспекти історичного музикознавства. 2018. Вип. 14. C. $122-131$.

3. Щетинський О. Вірко Балей: музичний міст між світом і Україною. Часопис Національної музичної академії України імені П. Чайковського. 2019. № 2 (43). C. 49-66.

4. Щетинський О. Музична іконографія Благовіщення: особистий досвід. Аспекти історичного музикознавства. 2019. Вип. 17. С. 60-73.

5. Щетинський О. Поза стенограмою. Неформальні історії про харківських композиторів. Критика. 2019. Ч. 5-6. С. 12-19.

3 Бентя Ю. Украинская панорама от Александра Щетинского. URL: http://m.day.kyiv.ua/ru/article/kultura/ukrainskaya-panorama-ot-aleksandrashchetinskogo. 
центрального розділу реквієму: спочатку - “Dies irae" («День гніву»), у центрі - "Тиbа mirum” («Дивний глас труби»), а в кінці - “Lacrimosa”. Фінал Концерту складає сьома частина "Lux aeterna" («Вічне світло»)» ${ }^{4}$. Композитор підкреслює, що він намагався зберегти типові риси інструментального концерту, причому зв'язок із традицією тут непрямий. «Наприклад, концерти, як правило, мають каденції розгорнутий віртуозний епізод, який виконується солістом без оркестру. У мене каденцією стала шоста частина "Lacrimosa", але це не віртуозний феєрверк, а дуже скромна за фактурою, зосереджена речитація соліста, тихе самозанурення. Іноді фортепіано замовкає, і тоді звучать литаври соло - точно так само тихо й зосереджено, із характерним ритмом на одній ноті, ніби проговорюючи молитву. Діалог фортепіано й литавр - це, звісно, алюзія на П'ятий фортепіанний концерт Бетховена $з$ литаврами в каденції. Мені завжди хочеться наповнювати музику такими зв'язками, входити в діалог із минулим. Звідси робота 3 різними стилями - історичними й авторськими. Я беру їхні окремі компоненти (мотиви, ритміку, гармонію тощо) й занурюю їх у контекст іншого стилю, іншої епохи, працюю зі стилем як із тематичним матеріалом. Звісно, цим методом користуюсь не лише я, це одна із провідних ідей сучасного мистецтва, i головна проблема тут - у знаходженні загального знаменника всіх використаних стилів. На ідейному рівні - це пошук того, що об'єднує строкату картину сучасного світу» 5 .

Сім частин Концерту організовані в III макрочастини, що відповідає традиційній композиційній структурі жанру. Однак драматургійна логіка й семантична структура циклу діють за оригінальним алгоритмом розгортання музичних подій. Частина виконує, як зауважує композитор, функцію прологу. У ній сконцентровано інтонаційні структури та звукокомплекси, а також фактурні й композиційні ідеї, із яких пророщена тканина всього Концерту. Це дає змогу трактувати I частину як породжуючу модель ${ }^{6}$ усього циклу. Звернімося до прикладів.

У т. 1 контрабасів divisi встановлюється педаль $E_{l}-B_{l}$, у віолончелей divisi - педаль $E s-F$. Надалі тритон у двох варіантах (зменшена

4 Бентя Ю. Украинская панорама от Александра Щетинского. URL: http://m.day.kyiv.ua/ru/article/kultura/ukrainskaya-panorama-ot-aleksandrashchetinskogo.

Бентя Ю. Украинская панорама от Александра Щетинского. URL: http://m.day.kyiv.ua/ru/article/kultura/ukrainskaya-panorama-ot-aleksandrashchetinskogo.

${ }^{6}$ Савченко А. Действие принципа порождающих моделей в Восьмой симфонии А. Брукнера. Молодий вчений. 2016. № 11 (38). С. 174-177. 
квінта/збільшена кварта) буде важливим (центральним, осьовим) елементом акордових структур в усіх частинах, він матиме й горизонтальне розгортання в мелодичних побудовах. Секунда (септима) у вертикальній і горизонтальній проєкціях $є$ ще одним осьовим елементом системи звуковисотної організації Концерту. Із секунди народжується інваріантна інтонаційна структура в партії фортепіано (т. 2) - пентахорд у межах зменшеної квінти (!) $a^{l}$ gis $^{l}$ fis $^{l} e^{l}$ dis $^{l}$, який у наступних тактах зазнає послідовних модифікацій, котрі полягають у варіюванні інтервальних структур, ритму, діапазону, розширенні амбітусу (від п'яти до дев'яти звуків у межах зменшеної квінти, чистої квінти, великої сексти). Зціплення модифікацій інваріантної інтонаційної структури вкладається у дванадцять тактів (т. т. 2-13), і це $є$ темою, яка стає основою тематичної роботи в I частині. Ї̈ «витягування» 3 першоструктури викликає асоціації з бароковим принципом «ядро й розгортання». Однак інтонаційна концентрованість процесу в межах дванадцятитакту змітає цю асоціацію. О. Щетинський не застосовує інтонаційно нейтральні елементи, які можна визначити як «розпилення», уся тканина Концерту $€$ максимально інтонаційно насиченою, тематизованою. Оперування стійкими інтонаційними та інтервальними структурами, їхнє комбінування по вертикалі й горизонталі сам композитор воліє визначати як «мікротематизм» ${ }^{7}$, накреслюючи його генетичну лінію від творчості композиторів Нової віденської школи. Із теми I частини проростає в результаті мікротематичної роботи тематизм усього Концерту. Як приклади назвемо теми в частинах II/3 (тембро-фактурний шар струнних від т. 20), II/5 (партії флейт від т. 29, партія фортепіано від т. 36). В остинатному шарі у віолончелей у

7 У контексті своєрідної наукової саморефлексії О. Щетинський розмірковує щодо специфіки тематизму своєї одноактної камерної опери «Благовіщення» (1998 рік): «Чітко окреслених тем у традиційному розумінні у творі немає. Відповідно, не вживаються й традиційні прийоми «тематичної роботи», добре відомі з музики класико-романтичної доби. Проте цю оперу не можна вважати атематичною. Вся іï музична тканина об'єднана за допомогою кількох мікротематичних інтервальних структур, що утворюють більшість мотивів і типові акордові сполуки, отже, стають джерелом як горизонталі, так і вертикалі. Головними складниками цих структур є тритон і мала секунда, що в умовах атональності й модальності втрачають якості нестійких інтервалів, не потребують розв'язання, а їхнє поєднання стає, користуючись терміном Юрія Холопова, центральним елементом звуковисотної організації. Різні форми поєднання малої секунди із тритоном - прямі та 3 октавним переносом, коли мала секунда обертається на малу ноту чи велику септиму, $-\epsilon$ основним звуковисотним «будівельним матеріалом» твору» (Щетинський О. Музична іконографія Благовіщення: особистий досвід. Аспекти історичного музикознавства. 2019. Вип. 17. С. 87-88). 
частині II/2, побудованому на невпинному русі шістнадцятими, вимальовуються стійкі інтервальні структури, що містять секунди, тритони, терції. Названі інтервали в різноманітних комбінаціях увіходять до акордових комплексів у партії фортепіано. Прикладом $\epsilon$ структура акордової вертикалі теми частини II/5; у процесі іiі розгортання з'являється інверсія інваріантної інтонаційної структури. Загалом ще раз підкреслимо велике значення секунди як вагомого конструктивного елементу вертикалі й горизонталі в усіх частинах. Зважаючи на висловлені самим композитором міркування щодо важливості секунди й тритону у звуковисотній організації опери «Благовіщення» і виявляючи ті самі інтервальні структури у творі, написаному через сімнадцять років, можемо сказати про важливість цих інтервалів як констант звуковисотної системи композитора.

У другому проведенні теми в партії фортепіано (т. т. 14-24) композитор застосовує прийом контрапунктичного поєднання теми та іiі інверсії. Це є репрезентацією ще однієї конструктивно-композиційної ідеї Концерту, адже поліфонічні прийоми відіграють в організації фактури велику роль, лінеарне мислення в ній $є$ панівним.

Ідеї тембрової організації I частини мають подальшу реалізацію у творі. Тема спочатку викладається у фортепіано, у наступній фазі розвитку (від т. 25) - у дерев'яних духових, далі (від т. 38) передається струнно-смичковим, у кодовому розділі тема, замикаючи коло, повертається до фортепіано. Переключення уваги з однієї тембрової групи на іншу, цілком природне й закономірне для великого твору, реалізується в продуманій тембровій драматургії: кожна частина має свій «тембровий акцент», реалізується завдяки вибраному тембровому комплексу, який визначає ії «фонічну» своєрідність.

Друга макрочастина є багатоскладовою, фактично вона є циклом у циклі, вписаним у ціле (містить п'ять частин від другої до шостої) зі своєю конфігурацією смислу й драматургійною логікою. Його єдність підкреслена прийомом attacca, що об'єднує частини від другої до сьомої. Однак доцентрові механізми композиційно-драматургічної організації взаємодіють тут із відцентровими, які реалізуються в образно-семантичному переключенні на рівні окремих частин: вихрова частина II/2 "Dies irae” змінюється мертвенно-застиглою II/3 “Quantus tremor" («Жах великий»); серцевину другої макрочастини утворює заклично-піднесена II/4 “Тиbа mirum”, після якої звучить зосереджена II/5 "Ingemisco et Confutatis” («Винуватий і Посоромивши»); нарешті,

8 Об'єднання прийомом attacca сьомої частини (тобто III макрочастини) із попередніми пояснимо далі.

9 У запропонованій нумерації римська цифра позначає макрочастину, яких у циклі три, арабська - частину наскрізної нумерації від першої до сьомої. 
смисловою кульмінацією мініциклу й усього Концерту можна вважати тиху молитовно-споглядальну II/6 “Lacrimosa". Тим самим накреслюється складна звивиста й розшарована драматургійна лінія від "Dies irae", яка, немов вихор, змітає все на своєму шляху, до споглядальної "Lacrimosa" як очищення та просвітлення. Ідея яскравого (дозволимо собі кольорову асоціацію - «сяючо-білого») світла закріплюється в сьомій частині “Lux aeterna”, яка завершує цикл, виконуючи функцію епілогу i, відповідно, III макрочастини. Не випадково композитор не відділяє їі від попереднього процесу, а вписує в спрямований до кінця твору (незважаючи на смислові вигини) драматургійний вектор прийомом attacca як логічним продовженням молитовного прохання "Lacrimosa".

Складне жанрове рішення Концерту на перетині жанрів принципово різних за функцією, структурою та семантикою провокує до виявлення їхніх типологічних ознак. Відсилання до реквієму виведене композитором на поверхню музичного тексту в програмних назвах частин і глибинно втілюється в підтексті, а саме драматургї твору, яку можна інтерпретувати узагальнено в досить широких смислових межах: «від відчаю до надії», «від смерті до життя вічного» i, як зауважує сам композитор, «від смерті до просвітлення» ${ }^{10}$. Риси концертного жанру вбачаються у віртуозності партї соліста, на чому наголошує композитор: «Я намагався зробити його (піаніста - Г. С.) партію зручною, при цьому наситити ії віртуозними елементами, для того щоб соліст міг виявити свої можливості» ${ }^{11}$. У партї соліста застосовані найрізноманітніші фактурні варіанти й конфігурації дрібної та крупної акордової техніки, у реалізації яких як репрезентантів концертності ${ }^{12}$ композитор демонструє високий ступінь фантазійності та винахідливості. При цьому підкреслимо ще раз, що мелодичні

\footnotetext{
${ }^{10}$ Концерт уписується в лінію духовних творів композитора, накреслену від ранньої творчості, i, як зауважує П. Рудь, є стійкою й виявленою не тільки в музиці, пов'язаній зі словом, але й у творах інструментальних (доповідь «Інструментальна духовна музика: новий канал комунікації (на прикладі твору «Моління про чашу» О. Щетинського)» на конференції «Музична комунікація в питаннях і відповідях» (15-18 січня 2021 року, м. Харків). Таким чином, Літургійний концерт для фортепіано 3 оркестром представляє ще одну проєкцію духовної тематики у творчості композитора, яка, справді, не має аналогів в історії музики.

Бентя Ю. Украинская панорама от Александра Щетинского. URL: http://m.day.kyiv.ua/ru/article/kultura/ukrainskaya-panorama-ot-aleksandrashchetinskogo.

${ }^{12}$ О. Антонова сумарно визначає ознаки, притаманні концертності як жанровостилістичному модусу музичного мислення, такі як «віртуозність парії соліста, колористичність, що виникає завдяки численному зіставленню tutti та solo, підвищена рельєфність тематизму, підкреслена фігураційно-пасажним матеріалом, переважання ігрової логіки розгортання матеріалу» (Антонова Е. Жанровые признаки инструментального концерта и их претворение в предклассический период : автореф. дисс. ... канд. искусств. наук : спец. 17.00.02. Киев, 1989. С. 7).
} 
побудови віртуозного типу з дрібною ритмікою не є демонстрацією самодостатнього технічного начала: вони органічно вписані в смисловий контекст твору, є виявом художнього задуму. Відхід від віртуозності фігураційного типу зумовлений і граничною інтонаційною концентрацією всіх складників музичної тканини, у тому числі віртуозних побудов. У цьому смислі показовим $є$ тематизм сьомої частини (фіналу), де, по-перше, наявною $є$ тонка мікротематична робота; по-друге, блискучо-віртуозна партія соліста $є$ виразним, у буквальному сенсі наочним утіленням ідеї сяючого світла, сяяння, чому сприяють дрібна моторика, необтяжена фактура й зосередженість на середньому та високому регістрах. Крупна й моторна техніка в "Dies irae" адекватно відповідає страшному напористому руху, який пронизує частину від початку до кінця.

Показовою щодо трактування сольно-віртуозного начала й композиційних структур, що його втілюють у концерті, $\epsilon$ II/6 частина "Lacrimosa", яку композитор із функціональної точки зору визначив як каденцію. Проте, на відміну від традиційної каденції, перед нами геть нетипове ії вирішення, а саме як зосередженого тихого ліричного висловлювання в діалозі (!) з литаврами. Ідея діалогу як суттєвої ознаки жанру й засобу виявлення концертності проникає в принципово монологічні композиційні структури. 3 іншого боку, у Концерті $є$ сольні фрагменти, які розосереджено реалізують ідею сольного висловлювання в межах концерту, чим частково перебирають на себе каденційні функції. Фортепіанним post scriptum завершується I частина, короткий сольний фрагмент міститься в II/4 (т. т. 23-29) як завершення фази розвитку, частину II/5 відкриває соліст, у партії якого звучить тиха тема в акордовому викладенні (до 29 т.). Підкреслимо, що названі сольні фрагменти вирішені в зоні тихого зосередженого висловлювання, що модифікує ідею концертності шляхом заглиблення у внутрішньо-ліричний простір. Це надає Літургійному концерту 3 об'єктивною надособистісною у своїй основі програмою особистісного психологічного виміру. На нашу думку, саме тут відбувається смисловий стик між концертом і реквіємом.

Гра та діалог у широкому розумінні, притаманні концерту, виявляються в обмінах тематизмом між солістом та оркестром і різними оркестровими групами. Таким чином, експонується тема I частини, а саме послідовно у фортепіано, дерев'яних духових і струнних. Тема в частині II/3 експонується спочатку у трьох флейт, після чого проводиться в партії фортепіано. У тембровій інверсії щодо II/3 із підключенням високих струнних звучить тема в частині II/5: спочатку у фортепіано solo, потім до іiі викладення підключаються флейти і партії I та II скрипок. 
Отже, значну роль у реалізації концертності відіграє оркестровка, а саме оркестрова фактура у її взаємодії з партією соліста. Склад оркестру в Концерті парний (із трьома флейтами), і засобами «не пишного», навіть «аскетичного» ${ }^{13}$ оркестру композитор вибудовує тонко прописану, рельєфну й колористичну оркестрову тканину. Систематизуємо основні принципи оркестрового письма в Літургійному концерті.

В оркестровій фактурі Концерту домінує лінеарне мислення, мелодичні «енергетичні» струми пронизують тканину на всіх рівнях ${ }^{14}$. Це досягається в результаті задіяння широкого спектру поліфонічних прийомів, а саме контрастної, імітаційної поліфонії, поліфонії на основі розщеплення мелодії (гетерофонії), мікрополіфонії. Як наслідок, тип функціональної будови оркестрової фактури можна переважно визначити як нон-ієрархічний, такий, у якому відсутній або максимально стертий функціональний розподіл на рельєф та супроводжувальні голоси. До цього ведуть також тотальна тематизація музичної тканини, відмова від інтонаційно нейтральних елементів у лініях та шарах оркестрової фактури, вишукана мікротематична робота. Можна сказати, що ступінь рельєфності лінії або тембро-фактурного шару в оркестровій тканині визначається iï інтонаційною концентрацією.

Навіть там, де оркестрова фактура тяжіє, на перший погляд, до гомофонно-гармонічного типу організації (частина II/2), наявність чітко окреслених візуально-графічних діагоналей шляхом застосування тембрових передач усередині груп і між ними, «вмонтовування» коротких реплік духових в остинатний шар струнних, під- та відключення інструментів у різних групах, надає їй поліфонічності й обширу, створених саме оркестровими засобами. Під- та відключення інструментів, яке застосовується, як правило, на короткий час, сприяє утворенню тембрової перемінності й тембрових акцентів, що унаочнюється в дискретній («візерунчатій)» оркестрової тканини.

Композитор тяжіє до функціональної диференціації тембрових груп оркестру. Це дає змогу оперувати тембро-фактурними шарами як структурними складниками макрополіфонічної цілісності; диференціювати тембри й «розраховувати колорит» в оркестрі по вертикалі й горизонталі; вибудовувати оптимальну щодо художнього задуму щільність тканини. Щодо останнього пункту зауважимо, що цьому сприяє прийом під- та відключення тембрів на короткий час.

13 Оркестрові колористичні «пишноти» складає хіба що група ударних інструментів, розрахована на одного виконавця: 2 Wood Blocks, Maracas, Snare Drum, Suspended Cymbal, Tam-tam, Glockenspiel.

14 Композитор підкреслює в цьому смислі вплив оркестровки В. Бібіка і Е. Денисова. 
Організація тембро-фактурних шарів в оркестровій фактурі Концерту доволі складно звести до стійких типів, адже настільки урізноманітнена їхня реалізація та взаємодія. Обережно систематизуємо їх у такі види:

1) взаємодія рівнозначних із точки зору функціональної організації тембро-фактурних шарів (наприклад, поліфонічних (І частина від т. 25));

2) взаємодія нерівнозначних із точки зору функціональної організації тембро-фактурних шарів (наприклад, один вирішений як сума педалей i виконує педальну функцію в макрополіфонічній цілісності, інший/інші поліфонічно, складається(ються) з інтонаційно-ритмічних виразних ліній (II/2 частина від т. 85; II/3 частина від початку));

3) взаємодія відносно рівнозначних шарів (наприклад, один вирішений на основі мікрополіфонії, інший - на основі поліфонії (III частина від т. 65)).

Тембро-фактурні шари можуть мати різноманітну внутрішню функціональну організацію, як одноріднішу, так i неоднорідну, складатися з різнофункціональних елементів і ліній оркестрової фактури.

Зауважимо, що кількість поєднаних у вертикальній проєкції шарів, ліній та елементів не перевищує гранично допустимої межі прослуховуваності. Композитор навіть у tutti мислить зрозуміло й прозоро, не виходячи в зону масштабного сонористичного багатоголосся, хоча відзначимо, що у фрагментах партитури, де застосовано мікрополіфонію, композитор оперує сонористичним звучанням, яке застосовується локально.

Оркестрова фактура в Концерті позначена функціональною мінливістю, що цілком відповідає тенденціям оркестровки XX - XXI ст. На це звертає увагу А. Шнітке, аналізуючи партитуру балету «Агон» I. Стравінського ${ }^{15}$. Звідси, а також унаслідок тонкої мікротематичної роботи та інтонаційної концентрованої насиченості всіх функціональних елементів оркестрової тканини можна говорити про іiі граничну деталізацію як щодо інтонаційно-ритмічної промальовки та індивідуалізації всіх елементів і ліній, так і в аспекті штрихової та динамічної конкретизації. У цьому смислі оркестрове письмо в Концерті набуває рис ансамблевого в умовах великого складу. Про перетин i, напевно, синтез власне оркестрового й ансамблевого типів письма свідчить диференціація партій усередині груп (divisi a3, a4 партій струнно-смичкових), трактування їх як солістів (у дерев'яній і мідній духових групах) й оперування ними як смисловими й функціональними одиницями в тих фрагментах партитури, де композитор досягає найвищого ступеня індивідуалізації ліній.

${ }^{15}$ Шнитке А. Парадоксальность как черта музыкальной логики Стравинского. И.Ф. Стравинский. Статьи и материальл. Москва : Советский композитор, 1973. C. 413. 
У тонко проробленій тканині постає питання про дублювання, частота застосування яких i їхні типи $є$ показником різниці між ансамблевим та оркестровим письмом. О. Щетинський дублювання застосовує, проте рідко унісонні або октавні, що можуть зустрітися в педалях, а частіше інтервальні (часто не в паралельному русі партій, а в паралельно-різноспрямованому), фрагментарні й варіантні, які можуть бути виявом мікрополіфонічної природи тканини; можуть приводити до гетерофонного розщеплення ліній, які беруть участь у дублюванні.

Окрім продуманої тембрової драматургії на рівні композиції циклу загалом, у Концерті можна говорити про семантичну трактовку окремих тембрів і тембрових комплексів, а також оркестрового простору. Композитор тут застосовує стійкі, напрацьовані традицією семантичні значення «низького» й «високого» як протилежних семантичних сфер. "Dies irae" починається остинатними жорсткими ходами віолончелей staccato в низькому регістрі за підтримки низьких контрабасів. На тембровий шар струнно-смичкових нашаровуються акорди у фортепіано, теж у низькому регістрі. Партію фортепіано в сяючому фіналі (“Lux aeterna”) вирішено переважно в межах середнього й високого дзвінкого - регістру. Відточена («гостра», світла) дзвінкість примножена іншими тембрами. Це передусім дзвіночки, які через свою «металеву» природу застосовані у контексті цієї частини композитором не випадково. Розповідаючи про темброві рішення в опері «Благовіщення», О. Щетинський зауважує, що «інструментальний склад і трактування всіх без винятку інструментів були нерозривно пов'язані 3 драматургійною концепцією й стали ії невід'ємною часткою» ${ }^{16}$. Саме таким - символічним - чином трактуються в опері фортепіано, челеста й ударні, при цьому композитор вибирає виключно металеві ударні ${ }^{17}$, трактуючи їх як такі, що пов'язані з небесним началом (за традицією, започаткованою О. Мессіаном) ${ }^{18}$. Дзвіночки в Концерті відкривають

${ }^{16}$ Щетинський О. Музична іконографія Благовіщення: особистий досвід. Аспекти історичного музикознавства. 2019. Вип. 17. С. 83.

${ }^{17} \mathrm{O}$. Щетинський надає список ударних інструментів в опері й коментує їхнє технічне й образно-семантичне трактування: «Список використаних ударних такий: індійські дзвіночки, лінійні (вітрові) дзвіночки, 5 трикутників (із різною висотою тону), 3 гонги (невеликі, так само звуковисотно різні), тамтам, кроталі (хроматичний набір із діапазоном від с4 до с5). Найбільш розвинуті партії мають кроталі та трикутники, особливо в першому епізоді, де вони разом із челестою утворюють спільний тембровий комплекс «дзвіночків», що звучать на тлі «шурхотіння» тамтама (тремоло або тертя, обидва прийоми застосовуються 3 використанням металевих мітличок). Важливо, що звучання всіх інструментів із групи «дзвіночків», включаючи п'ять трикутників, не лише $є$ колористичним засобом, але й часто містить мелодичні й тематично важливі фрази, що за характером наближаються до кантилени, отже, потребують хоча й прозорого, але доволі експресивного виконання». Там само. С. 83.

${ }^{18}$ Там само. С. 82. 
фінал ясними тріолями і протягом усієї частини точково нашаровуються на тріольний рух фортепіанної партії, темброво їі підсвічуючи.

Складна смислова конфігурація твору, зумовлена програмним задумом і композиційною будову циклу, наштовхує на думку про приховані смислові підтексти й коди. Розгляньмо числові закономірності організації циклу. Кількість частин у циклі (сім) відсилає до сакрального числа, яке можна вважати спільним символом для багатьох культур i релігій. Воно «використовується як основа великої кількості класифікацій об'єктів, подій, персонажів тощо» ${ }^{19}$, таких як сім Таїнств, сім доброчесностей і протилежних їм сім смертних гріхів, сім радощів $\mathrm{i}$ скорбот Діви Марії

Одним із геометричних символів сімки $є$ поєднання трикутника й квадрата $^{21}$. Смислові взаємини між частинами, об'єктивовані в тематизмі та оркестровій фактурі, дають змогу об'єднати в трикутник усі парні частини: "Dies irae" - "Tuba mirum" - "Lacrimosa" (при цьому вершиною трикутника буде серцевина циклу “Tuba mirum”). Рух від частини II/2 до II/6 здійснюється за наростаючою драматургійною лінію зі смисловими вигинами, яка веде до тихої кульмінації. У квадрат уписані всі непарні частини, такі як "Te decet hymnus" - "Quantus tremor" - "Ingemisco et Confutatis" - "Lux aeterna", на основі явних тематичних зв'язків. Частини II/3 та II/5 мають прямі кореляції з тематизмом I частини. У фіналі зв'язок із I частиною простежується більш опосередковано завдяки мікротематичній роботі та «вплетеними» в загальний інтонаційно-мелодійний потік осьовими інтервалами (секунда, тритон, терція) й інтонаційними структурами на основі їхнього комбінування.

Сім частин об'єднані в три макрочастини. Число три так само, як $\mathrm{i}$ сім, є складним і полісемантичним ${ }^{22}$. Троїстість у циклі виявляється на різних рівнях. Наприклад, I частина як модель цілого, що містить основні смислові й конструктивні ідеї, теж складається 3 трьох фаз розвитку з кодою.

${ }^{19}$ Число 7. URL: http://www.symbolarium.ru/index.php/\%D0\%A7\%D0\%B8\%D1\% $81 \%$ D0\%BB\%D0\%BE_7.

${ }^{20}$ Міфопоетична концепція числа 7 розкрита в такій роботі: Топоров В. О структуре романа Достоевского в связи с архаичными схемами мифологического мышления («Преступление и наказание»). Миф. Ритуал. Символ. Образ: Исследования в области мифопоэтического: Избранное. Москва : Прогресс Культура, 1995. С. 210-211.

21 Число 7. URL: http://www.symbolarium.ru/index.php/\%D0\%A7\%D0\%B8\% D1\%81\%D0\%BB\%D0\%BE_7.

${ }_{22}$ Аверинцев C. Вслушиваясь в слово: три действия в начальном стихе Первого Псалма - три ступени зла. Собрание сочинений / под ред. Н. Аверинцевой, К. Сигова. Связь времен. Київ : Дух і Літера, 2005. С. 23-30.

Аверинцев С. Девять чинов ангельских. София - Логос. Словарь. Киев : Дух і Літера, 2001. С. 70-71. 
Між частинами, як уже було сказано, встановлюються системи арочних зв'язків, які слугують своєрідними контрфорсами, що тримають на собі велику композицію. Смислова арка перекидається від I частини (прологу) до фіналу (епілогу), при цьому накреслений між ними смисловий вектор пронизує весь твір. Одночасно взаємопов'язану та в певному смислі опозиційну пару утворюють II/2 "Dies irae" i II/6 "Lacrimosa", яка $\epsilon$ і породженням II/2, і протиставленням їй. Нагадаємо, що сам композитор вважає частину II/6 смисловою кульмінацією циклу. Далі між частинами I/1, II/3, II/5 та III/7 встановлюються відносини на основі очевидної спорідненості інтонаційних структур. Ми вже звертали увагу на симетричні щодо тембру складники в частинах II/3 та II/5, на зв'язок тематизму I частини з тематизмом інших частин як своєрідної моделі для подальшої композиторської роботи.

Складання такої продуманої до найдрібніших клітин музичного тексту геометрії наводить на думку про своєрідну «сакральну геометрію» музичного тексту як віддзеркалення в музичних конструктах геометрії Всесвіту.

\section{2. Музичні коди «Землі Франца Йозефа»}

Твір для оркестру «Земля Франца Йозефа» (2011 рік) не має жанрового найменування. На титульній сторінці написано ««Земля Франца Йозефа» для оркестру». Це становить для дослідника перший код, який має бути розшифрований. Другий код - це задум твору, який $\epsilon$ авторською передмовою-коментарем і в якому проартикульована ідея нового стильового синтезу як ключова для сучасної музики: ««Земля Франца Йозефа» відтворює обрис першої частини клавірної сонати Гайдна мі-бемоль мажор (KH XVI, 49). Матеріалом для нового твору стали як теми Сонати, так і допоміжні складники (акомпанемент, сполучники, пасажі тощо). Форма сонати Гайдна повністю збережена, хоча всі ії розділи зазнають суттєвого варіювання й розширення - іноді ледь помітного, часом доволі радикального. Початковий темп Allegro жодного разу не змінюється, а весь твір $€$ одночастинною перманентною варіацією, складеною в сонатній формі. Емоційний спектр музики доволі широкий: від світлого життєствердження до драматизму й трагізму. Так само різною є стилістика: від класичної тональності через складнішу гармонію до жорстких дисонантних сполучень, атональності й сонорних фактурних нашарувань. Симфонічні ідіоми, типові, зокрема, для Моцарта, Бетховена, Шуберта, Брамса, Малєра, Шостаковича, утворюють «ланцюжок», на початку якого стояв Гайдн. Хоча стильові складники твору походять із різних часів, шкіл та естетик, переходи між ними $є$ плавними, часто вони глибоко інтегровані один в одного. Я ніколи не протиставляю свого 
«коментаря» музиці Гайдна. Навпаки, мені йшлося про знаходження спільного знаменника між різними стилями й культурами, що міг би стати ознакою нового стильового синтезу. Таким чином, третій код - це засоби реалізації ідеї нового синтезу. Спробуємо розшифрувати закладені в музичному тексті коди.

Відсутність жанрового найменування може свідчити про оригінальне (непросте) жанрове рішення як утілення констант композиторського мислення самого О. Щетинського і одночасно як вияв того синтезу, про який ідеться у передмові. На питання автора статті про те, чи можна назвати цей твір концертом для оркестру, композитор відповів, що частково. Отже, перед нами є результат складної міжжанрової взаємодії, де зашифровані ознаки оркестрового концерту й варіацій.

Жанр концерту для оркестру виявляється явно й глибинно. У першому випадку це відбувається у грі, діалозі між оркестровими групами й окремими тембрами, між звучаннями різної щільності й тембрового наповнення, що стають провідною ідеєю всього твору. Власне, головним принципом організації оркестрової фактури по горизонталі є принцип тембрової гри та тембрових діалогів. У другому випадку йдеться про діалог щодо звернення до I частини сонати Гайдна як вихідної моделі, яка задає певний тематично-композиційний алгоритм i трактується як «база» будівельних елементів нової композиції. У цьому смислі діалог можна трактувати в аспекті культурно-контекстуального (парадигматичного) діалогу, адже розгортання музичного процесу в синтагматичній вісі ускладняється парадигматичними зв'язками із сонатою Й. Гайдна й відсилками до «симфонічних ідіом» композиторів минулого, що розсуває смисловий простір твору та встановлює діалогічно-комунікативні канали між стилем О. Щетинського та стилями названих у передмові композиторів. «Пошуки спільного знаменника», про які говорить О. Щетинський, $є$ теж своєрідною грою, «надзавданням» для композиторського мислення й композиторської техніки. У цьому смислі гра стає основою ретроспективно орієнтованого комунікативного процесу в просторі й часі музичної культури, а також комунікації між композитором i реципієнтами.

Гра й фантазійність формують і визначають драматургійний процес, що вибудовується над заданим сонатою тематично-композиційним алгоритмом, тому драматургійний рельєф «Землі Франца Йозефа» є абсолютно індивідуальним зі своїми смисловими вигинами, кульмінаціями й спадами, вплетінням драматичних $\mathrm{i}$ трагічних моментів, тільки пунктиром, обережно «намічених» на початку й наприкінці розроблення в першоджерелі. Їхня наявність свідчить про 
масштабність задуму твору О. Щетинського, вихід за межі “Kundstück” у поле серйозних смислів та ідей. Їхнє приховування на початку 3 виявленням надалі $€$ також своєрідною грою в розкриття зашифрованих смислів і кодів.

Масштабності задуму відповідає крупна форма. Її розгорнутість досягається завдяки «розсуванню» в прямому смислі слова гайднівської сонатної форми варіаційним перетворенням матеріалу; багатофазовій розробці, у якій відбувається активна тематична робота із залученням «симфонічних ідіом» і відходом від тематичного першоджерела, вибудовується непроста драматургія з кількома кульмінаціями; репризі, котра трактується як нова фаза розвитку із залученням інокультурного $^{23}$ щодо першоджерела матеріалу («ідіом» Шостаковича), який «врізається» приблизно в зоні точки золотого перетину й «знімається» класицистською «ідіомою». Таке трактування форми як багатоетапного, багатоскладового процесу, глибинну основу якого становлять загальні естетичні принципи організації художньої цілісності в європейському мистецтві Нового часу (гармонія, міра, симетрія, риторична диспозиція, антропоцентричні час та простір), $є$ свідченням знаходження композитором «спільного знаменника» для об'єднання різноджерельних елементів на рівні організації композиції.

Гра визначає також варіаційну роботу 3 вихідним матеріалом, не однолінійно-одноканальну в горизонтальній розгортці, а багатоелементну, в якій задіяні роз'єднані елементи гайднівської фактури. Завдяки масштабній диференційованій варіаційній роботі варіації проростають у концерт, або концерт об'єктивується у варіаційній формі. Варіаційна форма зростається із сонатною як базисом музичного процесу, первісним алгоритмом розгортання музичних подій.

Пошук «спільного знаменника» як надзавдання-гра для композиторської техніки на рівні організації тематизму й звуковисотності приводить до оперування різними композиційними структурами й різними системами звуковисотності. Композитор працює 3 темами та мікротематизмом. Тема Й. Гайдна як цілісна структурно-семантична одиниця експонується на початку твору, в репризі, піддаючись тембровому фрагментуванню (яке супроводжується тембровим переінтонуванням), що, на нашу думку, є засобом iii адаптування до умов сучасної оркестрової фактури. Здебільшого композитор працює з фрагментами й окремими елементами тематизму сонати, а також «симфонічними ідіомами». Варіювання полягає в проростанні (переростанні) тематизму у мікротематизм, своєрідному

${ }^{23}$ На нашу думку, «симфонічні ідіоми» Моцарта, Бетховена, Шуберта, Брамса, Малєра належать єдиному смисловому простору класико-романтичного музичного мистецтва. 
заміщенні інтонацій тематизму Й. Гайдна і «симфонічних ідіом» стійкими для мікротематичної техніки композитора інтервальними структурами (секунда, терція, тритон). Заміщення-проростання може бути повним, коли тема буквально розчиняється, розпилюється у мікротематизмі. Воно може бути частковим, коли елементи теми комбінуються з інтервальними структурами у горизонтальній проєкції; мікротематичні лінії нашаровуються по вертикалі на тематичні елементи (наприклад, у вигляді quasi(!)-фігураційного руху ${ }^{24}$ ). Варіаційна форма трактується як багатоелементна, розосереджена і диференційована.

Тематичні фрагменти організовані тонально, проростаючи у мікротематичні, вони «модулюються» у зону розширеної тональності або атональності. У звуковисотній організації композитор знаходить «спільний знаменник» у «ковзанні» на межі різних систем, що відповідає ідеї нового синтезу в сучасній музиці.

Балансування на межі декількох систем мислення спостерігається також в оркестровці. Склад оркестру у творі вельми прикметний, а саме парний із двома валторнами i трьома тромбонами. Такий склад утвердився на початку XIX ст., проте слід зауважити, що у першій половині століття кількість валторн могла коливатися від двох до чотирьох, а тромбони застосовувалися не завжди. Дещо дивним, на перший погляд, $є$ внесення арфи до зріло-класицистського або ранньоромантичного типу оркестру, адже відомо, що цей інструмент дуже рідко застосовувався в симфонічному оркестрі до середини XIX ст. Проте арфа у творі виконує важливу функцію медіатора між тональнотематичними й розширено-тональними або атональними епізодами мікротематичної організації. Це можна пояснити тим, що тембр арфи не відповідає образу звучання класицистського оркестру, іiі звучання допомагає модулювати в інший тематичний, звуковисотний, тембровий, семантичний простір, у якому вона застосовується як повноправний інструмент. Окрім того, характерне арфове відлуння темброво-фонічно сприяє «розмиванню», «розхитуванню» відчуття тональності й «модуляції» в розширено-тональну або атональну сферу.

В оркестровому письмі «Землі Франца Йозефа» застосовуються прийоми традиційної оркестровки в тих фрагментах, де композитор оперує 3 темою як структурно-семантичною цілісністю. Йдеться про чітку ієрархічну будову оркестрової фактури 3 виділенням мелодії, баса, супроводжувальних голосів; застосування формул акомпанементу, що склалися в класицистській оркестровці; вибір тих тембрів для викладення мелодичної лінії, яким це найчастіше

\footnotetext{
24 Підкреслена нами «несправжність» фігураційного руху обумовлена інтонаційною концентрацією всіх ліній.
} 
доручалося в добу класицизму. Незважаючи на наявність таких тонально-тематичних «острівців», у творі домінує оркестровка «діагонально-горизонтальна», темброво-колористична, яка виявляється 3 перших тактів у буквально наочному русі по діагоналі вгору від низьких струнних до двох флейт. Графічна діагональ промальовується також у результаті тембрового перезабарвлення тематизму, вельми гнучкого й колористичного. Наприклад, перший елемент теми головної партії («питання») звучить у I кларнета, а другий («відповідь») передається I скрипкам із низхідним контрапунктом у II скрипок та альтів. Друге проведення цих елементів відбувається із застосуванням тембрової симетрії: перший елемент звучить у віолончелей, а «відповідь» - у I гобоя в контрапункті з кларнетами. Відповідно до тембрової симетрії, у викладенні мелодії дзеркально переставляються супроводжувальні голоси: акомпанемент низьких струнних у першому проведенні передається фаготам у другому. Тембровому перезабарвленню піддається також кадансуюча фраза, поділена між I скрипками та I кларнетом із завершальним розчерком у I фагота. Такі колористичні темброві передачі визначають темброву логіку й надалі, акцентуючи діагональний вимір оркестрової фактури й вибудовуючи своєрідний тембровий рельєф тканини, вельми примхливий.

Однак діагональний вимір не витісняє й не зменшує значення горизонталі в досліджуваній партитурі. Значення горизонтального мислення й оркестрової фактури на основі індивідуалізованих ліній відзначалися нами в Літургійному фортепіанному концерті. О. Щетинський мислить поліфонічно, а в оркестровій фактурі він застосовує різноманітні прийоми оркестрової поліфонії, такі як під- та відключення партій на короткий час, використання варіантних, фрагментарних дублювань, коротких контрапунктів, розщеплення ліній, які надають оркестровій фактурі просторовості й обширу, полілінійності складної конфігурації та різного функціонального походження, полішаровості. При цьому винахідливість у застосуванні прийомів $\epsilon$ константною ознакою композиторського мислення О. Щетинського, яка, на нашу думку, корелює композиторській фантазійності самого Й. Гайдна 25 , котра визначена В. Бобровським як «іманентна ініціативність» ${ }^{26}$. Цікаво відзначити, що, як і в багатьох зрілих симфоніях Й. Гайдна, реприза (тематична й тональна) у О. Щетинського піддається тембровому перекомбінуванню. Від т. 478 перший елемент теми звучить у альтів за підтримки віолончелей $\mathrm{i}$

${ }^{25}$ Савченко Г. Тематичні та темброві процеси в сонатних allegri Паризьких симфоній Й. Гайдна. Традиџї̈ та новації у вищзій архітектурно-художній освіті. 2019. № 1. С. 87-91.

${ }^{26}$ Бобровский В. Темо- и формообразование в творчестве Гайдна позднего периода. Статьи. Исследования. Москва : Советский композитор, 1988. С. 60. 
контрабасів, другий - у I валторни з контрапунктом у фаготів. Друге проведення розподілене між двома партіями скрипок, яким відповідають дві флейти й I кларнет у контрапункті 3 гобоями та фаготами за акомпануючої підтримки струнно-смичкових.

Незважаючи на оригінальне оркестрове письмо, композитор застосовує традиційну диспозиційну логіку на рівні оркестровки: експозиція та реприза оркестровані більш цілісно, континуально (навіть за наявності тембрових передач, тембрової фрагментаризації тематизму), розроблення - більш дискретно. Використовує О. Щетинський i традиційну темброву семантику, пов'язуючи «симфонічні ідіоми» 3 певними тембрами, певним образом звучання.

Коди «Землі Франца Йозефа» розмивають звичний історикокультурний герметизм, у якому реципієнту затишно й спокійно. Вони апелюють до тезаурусу реципієнта, пробуджують його фантазію. Щодо наукової рефлексії, то без усвідомлення того, що сучасна композиторська практика - це творення «на межі», свідомо чи несвідомо в контексті «нового стильового синтезу», коди й смисли нової музики ризикують залишитись не розшифрованими.

\section{ВИСНОВКИ}

Ключем до розшифрування кодів і смислів інструментальної музики О. Щетинського $є$ ідея «нового стильового синтезу», яка $\epsilon$ наскрізною у його творах останніх двох десятиліть $\mathrm{i}$ часто визначальною у вибудовуванні художньої концепції і жанрового рішення.

В художніх концепціях досліджуваних творів наявні смислова полішаровість, глибинні смисли. В Концерті це запрограмоване перетином жанрів принципово різних за походженням і функціонуванням, а саме світського концерту і релігійного реквієму. В «Землі Франца Йозефа» задум розмикає твір в історико-культурний контекст, встановлює парадигматичні зв'язки з минулим музичного мистецтва, а саме музикою Гайдна, Моцарта, Бетховена, Шуберта, Брамса, Малєра, Шостаковича. Складна міжжанрова взаємодія присутня в цьому творі: в ньому простежуються риси оркестрового концерту й оригінально трактованих макроваріацій.

Ознакою нового стильового синтезу $\epsilon$ вільне оперування композитором різноманітними композиційними структурами й звуковисотними системами. Розосереджена каденційність в Концерті $\epsilon$ одним із таких прикладів. В «Землі Франца Йозефа» композитор працює як із темами, так і з мікротематизмом, відповідно, мислить тонально, розширено тонально, атонально. Основу звуковисотної організації Концерту складають розширена тональність, модальність, атональність за інтонаційної концентрованості музичного процесу завдяки детальній мікротематичній роботі. 
Оркестрове письмо композитора визначено нами як «діагональногоризонтальне», темброво-колористичне. В ньому наявні диференціація функцій оркестрових груп, оперування тембро-фактурними шарами, семантизація тембрів.

У стрункій і продуманій у кожній клітині композиційній будові творів зашифровані числові закономірності, закладені загальноестетичні ідеї симетрії, гармонії, міри, що є основоположними для європейського мистецтва Нового часу. Збереження їх як базису організації композиції у взаємодії і синтезі 3 новими засобами організації звукоматерії є свідченням «нового стильового синтезу».

\section{АНОТАЦІЯ}

У роботі вперше досліджено твори сучасного українського композитора О. Щетинського «Літургійний фортепіанний концерт» (2015 рік) та «Земля Франца Йозефа» для оркестру (2011 рік). Виявлено специфіку жанрових рішень творів, розглянуто особливості їхньої композиції та драматургії. Акцентовано увагу на мікротематизмі як принципі тематичної роботи композитора, виділено константні інтервальні структури (секунда, тритон, терція). Систематизовано принципи оркестрового письма (домінування горизонтального мислення, широке застосування прийомів оркестрової поліфонії, акцент на діагоналі та горизонталі, диференціація функцій оркестрових груп, тяжіння до тембрової колористичності тощо). Підкреслено важливість числових закономірностей, симетричних структур, породжувальних моделей в організації тематизму й композиції. 3'ясовано смислові конотації концептів «Гра» та «Діалог» у зв'язку 3 вибраними творами. Виявлено специфіку композиторського мислення й композиторської техніки О. Щетинського в аспекті «нового стильового синтезу».

\section{SUMMARY}

"Liturgical Concerto" for piano and orchestra was written in 2015 and devoted to pianist and conductor Denys Proschayev (born 1978), who had commissioned this work. Seven movements of the Concerto are organized into three macro-movements, which represent traditional structure for the genre. The I movement has a function of prologue. It is rich with intonational structures and sonic complexes, from which the texture of the next movements will be derived. Manipulation with constant intonational and intervallic structures (such as second, third, tritone) and their combination in vertical and horizontal axes is defined by the composer as "microthematicism".

The II macro-movement is multi-elemental; it is a cycle within bigger cycle, integrated into the whole (as it is constituted by the movements 
II -VI). Its unity is underscored by usage of the attacca device, uniting movements from II to VII. Seventh movement plays a role of the Finale.

Complexity of the Concerto's genre, it being on the intersection of genres, different by their functions, calls for examination of their typological features. Allusion to Requiem lies on the surface, but at the same time it is deeply ingrained in the subtext, dramaturgy, which might be interpreted rather generally in rather broad sense: "from death to transfiguration". The features of the concerto as a genre can be discerned in virtuosity of the soloist's part, featuring wide range of various texture types and configuration of technique types; using them as representatives of concerto the composer demonstrates great level of fantasy and invention.

Concerto features are largely embodied in the orchestration. The orchestral texture of the Concerto is governed by linear thinking. This is achieved by active usage of polyphony in its different types, such as contrast, imitational, splitting of the voice (heterophony), micropolyphony. Consequently, the type of functional structure of the orchestral texture can be defined as non-hierarchical. The composer leans towards functional differentiation of timbre groups of the orchestra. Orchestral texture changes quite often, in accordance with the general tendencies of the orchestration in $\mathrm{XX}-\mathrm{XXI}$ centuries. This, as well as intricate microthematic work and every element of orchestral texture being intonationally concentrated, allows to state that orchestral texture is extremely detailed. Apart from thought-out timbral dramaturgy on the level of the whole composition in the Concerto we can regard semantic interpretation of separate timbres and timber complexes as well as of orchestral space.

Complex configuration of the work's content, conditioned by the program and composition of the cycle, provokes a thought about hidden senses and codes. Thus, we will regard numerological structure of the cycle. Seven, the number of movements in a cycle alludes to a sacral number, which might be understood as a shared symbol for many cultures and religions. The seven movements are joined into three macro-movements. The number three (as well as seven) is complex and polysemantic. Ternarity in a cycle can be observed on different levels. For instance, the First movement as a model of a whole, containing main constructive and musical ideas, is as well constituted by three phases of development with a Coda. Between the movements, as it was mentioned before, there is a system of arch-like connections which integrate them into a whole composition. The fact that the composer creates "geometry" from painstakingly wrought cells of musical text leads to a thought about "sacral geometry" of musical text as a geometry of the Universe, reflected in music constructs.

Orchestral work with the title "Franz Joseph Land" (2011) does not have genre definition. Its avoidance might betoken original genre as an incarnation of constants of O. Shchetynskyi's composer thinking; but at the 
same time, it is a sign of genre synthesis. What we have is a result of complex interaction of genres, a mixture possessing hidden traits of concerto for the orchestra and variations.

Genre of concerto has its profound yet obvious influence. Firstly, it is reflected in the play, in the dialogue between orchestral groups and different timbres, between sonorities of various density and timbre; in a play being a principal idea for the work. Secondly, we mean the appeal to the I movement of J. Haydn's Sonata, usage of it as a model creating thematic and compositional algorithm, its interpretation as "warehouse" of elements, from which new composition will be constructed. In this sense, dialogue can be regarded from the standpoint of culturally-contextual (paradigmatic) dialogue: unfolding of the musical process on syntagmatic axis is complicated by paradigmatic relations with J. Haydn's Sonata and by allusions to "symphonic idioms" of the composers of the past.

Play and fantasy define dramaturgical process which develops above thematic and compositional algorithm, defined by sonata form. Moreover, play also governs multi-elemental variative work with initial musical material, which operates with detached elements of J. Haydn's texture. Thus, variations grow into a concerto, or concerto is being objectified in the form of variations. Consequently, the form of variations intertwines with the sonata form as the latter becomes a basis for musical process, primary algorithm for development of musical events.

Seeking for "common denominator" as a super-task, goal of play as a feature of composition technique on the levels of thematicism and pitch organisation results in manipulation with different compositional structures and pitch systems. The composer works with regular themes, with microthematicism, with tonality, expanded tonality and atonality. In microthematicism he uses constant intervallic structures (such as seconds, thirds, tritones).

Traditional devices of orchestration are used in the fragments of "Franz Joseph Land", where the composer operates the theme as structurallysemantic integrity. However, the majority of the work's orchestral texture is governed by timbrally-coloristic "diagonally-horizontal" orchestration, where polyphonization of the texture and dovetailing between timbres play a significant role.

Thus, we suppose that the key to decipher codes and senses of O. Shchetynsky's instrumental music is the idea of stylistic synthesis, shared between his works of the last two decades and often defining the construction of their artistic conception and genre.

\section{ЛIТЕРАТУРА}

1. Аверинцев С. Вслушиваясь в слово: три действия в начальном стихе Первого Псалма - три ступени зла. Собрание сочинений / под ред. 
Н. Аверинцевой, К. Сигова. Связь времен. Киев : Дух і Літера, 2005. C. 23-30.

2. Аверинцев С. Девять чинов ангельских / С. С. Аверинцев. София- Логос. Словарь. Київ: Дух і Літера, 2001. С. 70-71.

3. Антонова Е. Жанровые признаки инструментального концерта и их претворение в предклассический период : автореф. дисс. ... канд. исскусств. наук : спец. 17.00.02. Киев, 1989. 19 с.

4. Бентя Ю. Украинская панорама от Александра Щетинского. URL: $\quad$ http://m.day.kyiv.ua/ru/article/kultura/ukrainskaya-panoramaot-aleksandra-shchetinskogo.

5. Бобровский В. Темо- и формообразование в творчестве Гайдна позднего периода. Статьи. Исследования. Москва : Советский композитор, 1988. С. 59-94.

6. Савченко Г. Тематичні та темброві процеси в сонатних allegri Паризьких симфоній Й. Гайдна. Традищї та новащії $у$ вищій архітектурно-художній освіті. 2019. № 1. С. 87-91.

7. Савченко А. Действие принципа порождающих моделей в Восьмой симфонии А. Брукнера. Молодий вчений. 2016. № 11 (38). C. $174-177$.

8. Топоров В. О структуре романа Достоевского в связи с архаичными схемами мифологического мышления («Преступление и наказание»). Миф. Ритуал. Символ. Образ: Исследования в области мифопоэтического: Избранное. Москва : Прогресс - Культура, 1995. C. $193-258$.

9. Число 7. URL: http://www.symbolarium.ru/index.php/\%D0\%A7\% D0\%B8\%D1\%81\%D0\%BB\%D0\%BE_7.

10. Шнитке A. Парадоксальность как черта музыкальной логики Стравинского. И. Стравинский. Статьи и материаль. Москва : Советский композитор, 1973. С. 383-434.

11. Щетинський О. «Земля Франца Йозефа» для оркестру. Партитура. Рукопис. 134 с.

12. Щетинський О. Музична іконографія Благовіщення: особистий досвід. Аспекти історичного музикознавства. 2019. Вип. 17. С. 74-89. DOI: 10.34064/khnum2-1705.

\section{Information about the author: Savchenko H. S.,}

Candidate of Art History, Associate Professor, Associate Professor at the Department of Composition and Instrumentation Kharkiv National I. P. Kotlyarevsky University of Arts 11/13, Konstitutsii sq., Kharkiv, Ukraine 